\title{
LAND READJUSTMENT FOR REGULARIZATION OF INFORMAL SETTLEMENTS
}

\author{
Robina Manandhar \\ Department of Architecture, Khwopa Engineering College, Libali, Bhaktapur
}

\begin{abstract}
Regularization of informal settlements involves the process of legalization of tenure and upgrading of public services and infrastructures through land development. However, some settlement manages to get the services from formal authorities but lags legal tenure security. Legalization of tenure security is important so as to reduce their threat of eviction from formal authorities and improvement of their living standard. Various land development tools involves upgrading of public services and development of infrastructures but legalization of tenure security is left behind. Land development and legalization of tenure security both are the important components for regularization of informal settlements and recognize as formal settlements. Land readjustment is the tool or technique commonly used for the land development in Nepal. Thus this paper aims to indentify the applicability of land readjustment in regularization of informal settlement. In Nepal, there are prominent numbers of informal settlements along the river banks and also in urban core areas. Chadani tole along the Bagmati River is taken as a case study and analysis of applicability of land readjustment under the social and legal condition for regularization is carried out.

This research has adopted both desk research and case study methodology. Qualitative and quantitative data analysis is adopted in this study. The results of research reveal that public participation and long term occupancy are the social positive aspects for the application of LR in informal settlements. Lack of land registration, legal recognition and development regulations are the legal hurdles for the application of LR in informal settlements. Land registration of informal settlement has not been done in Nepal which is important aspect for application of LR. Thus land registration of Nepal should include the components of STDM for the pro poor land registration and recognition of social tenure to informal settlements. Applicability of LR is difficult due to the lack of sufficient area. So to address the issue and ascertain the rights of dwellers to live in the same area, high rise apartments can be adopted.
\end{abstract}

Keywords: Regularization of informal settlements, Legalization of tenure security, Land Readjustment

\section{Introduction}

Informal settlements have various definitions like slum which means lagging of basic infrastructure, housing violating land use and building norms, land bought outside formal land transactions. Such settlements are developed either on private lands or on public lands and are rapidly increasing in the urban areas, basically in developing countries (Fernandes, 2011).

\footnotetext{
*Corresponding author: Robina Manandhar

Department of Architecture, Khwopa Engineering College,

Libali-8, Bhaktapur, Nepal

Email: robi_na123@hotmail.com

(Received: 10 $0^{\text {th }}$ June 2018 Accepted: 18 ${ }^{\text {th }}$ April 2019)
}

The causes of informal settlements are mainly the rapid population growth and urbanization, poverty, natural disasters, climate change, migration from other regions (Potsiou, 2014). Although the settlements lag legal recognition, there are cases where these settlements are managed to get the utilities services from formal authorities itself. Due to lack of legal land documents, these settlements are always in threat of eviction from formal authorities (Shrestha,2013). Therefore, regularization of informal settlements is essential to protect from eviction.

Regularization of informal settlement involves the process of legalization of tenure through titling and 
also upgrading the public services and job opportunities (Fernandes, 2011). The provision of tenure security is the major step in regularization of informal settlement which ensures dwellers of informal settlement that they cannot be evicted by administrative decision (Ramadhani, 2007). The various land development tools such as land readjustment, Guided land development (GLD), land sharing, community land trust, transfer of development rights seems to be appropriate for upgrading public services and infrastructure (Berrisford et al., 2012). This study is focused on Land readjustment as a tool or technique for the infrastructure development in the settlement. Land readjustment is basically land development tool which focuses on infrastructure facilities. The process of land readjustment is wholly or partially financed by land owners and they contribute their portion of land for the streets, parks and other public places (Larsson,1997). Land development tools mainly focus on public services and infrastructure development but tenure security is left behind. Therefore the land development tools which are implemented for the regularization of informal settlement should include the guarantee of tenure security. Land Readjustment can be implemented efficiently under some important conditions. Among all other land development tools, land readjustment can be a possible alternative technique for land development of informal settlements because of its cost recovery and its popularity among developing countries. In the case of Turkey, after the determination of land rights, land development is carried out with the help of land readjustment. (Özdemirli, 2014) The focus of this paper is mainly towards the application of land readjustment under the social and legal conditions for regularization of informal settlement with secure land tenure.

\section{Research Objective:}

The objective of the study is to identify the application of land readjustment for regularization of informal settlement focusing on legalization of tenure security.

\section{Research Materials and Methodology}

The study is initiated with theoretical base, review of scientific articles, journals and books, to get knowledge regarding the areas prior to the need of research. The research has followed two different methodologies i.e. desk study methodology and case study methodology.

\subsection{Literature Review}

Regularization of informal settlement involves legalization of tenure security and upgrading of basic infrastructures i.e. land development. Regularization ensures the informal settlements from eviction and can continue to settle with tenure security and access of proper services and infrastructure.

\subsubsection{Current Context of Regularization of Informal Settlement in Nepal}

The early development of squatter settlement in Nepal was due to natural calamities (Sengupta and Sharma, 2009). The growth of such settlements is particularly due to the rural urban migration. Kathmandu, capital city of Nepal, has the highest concentrations of population and fastest growth of urban squatter settlement. In the city there were only 17 squatter settlements in 1970s but it has been increased to 64 settlements by 2003 and is population increased from 2,134 to 14,500 (Shrestha, 2013). People living in such settlement suffer from poverty and the places where they are residing are environmentally and legally vulnerable. They live in threat of eviction but they are socially recognized which made them strong to resist eviction (Shrestha et al., 2014). The issues of slums and squatter have been acknowledged by government in National Shelter Policy 1996, National Urban Policy 2007 and in Tenth Development Plan 2002-2007 for construction of cost effective shelter and provide basic services and facilities. District level committee of "Sukumbasi Samasya Samadhan Ayog" (Landless Commission) was established in 25 different districts which aim to identify genuine informal settlements. But the Government is facing problem to identify genuine settlers as the recording of informal land tenure system has not been done officially by government of Nepal. So due to the lack of reliable data, policies 
and programmes for upgrading and regularizing such areas cannot be carried out (Shrestha, 2013). DUDBC has initiated programs of housing for low income groups i.e. People Housing Program (Janata Aawash). It is a well planned and structured program which rely solely on governments grants. The program has been carried out in Siraha, Saptari and Kapilvastu district in 2009 for low income group (Ministry of Urban Development, 2014). In coordination with Lumanti(non government organization working for the upliftment of informal settlements and marginalized communities in the cities and towns of Nepal), Asian Coalition for community action (ACCA) project was launched at salyani informal settlement in Bharatpur as on-site upgrading program (UN-HABITAT, no date). It is considered as a first community housing and settlement upgrading program. Government has initiated apartment for urban poor in Ichhangu Narayan Land Pooling site. DUDBC bought the sales plot for the urban poor in which five apartments has been constructed in cooperation with KVDA. But due to poor policy of resettlement, it has not been implemented.

Several cases of eviction have been witnessed by the informal settlers of Kathmandu valley. Political instability in the country has also led to the number of eviction. Eviction in January 2002 which took place along the Bagmati river is one of the most disturbing eviction. It was carried out as a part of government plan so as to increase the security for South Asian Association for Regional Cooperation (SAARC) summit. Most of the cases of eviction of informal settlements were not followed by resettlement project except in Kirtipur housing project (Shrestha, 2001). Kirtipur Housing project is considered to be a successful project of resettlements of informal settlement with cost recovery scheme (Sengupta and Sharma, 2009). The project resettled three settlements, along Vishnumati river, during the construction of Vishnumati Link Road with the help of Lumanti. But there are many other cases of relocation which are unsuccessful due to various social and technical factors. Failure of relocation of Thapathali settlements can be taken as an example. In that case Government was unable to relocate the settlement. Local people protested against relocating them because they perceive that squatter will spoil their environment. Governmentbecame unable to select the appropriate area to relocate the settlements (Shrestha et al., 2014).

\subsubsection{Land Readjustment}

Land readjustment is the process which involves land owner itself living in the area where development is being done. Land readjustment is adopted for urban expansion, disaster recovery, development of new towns and industrial estates etc ( $\mathrm{Li}$ and $\mathrm{Li}, 2007$ ). But its application in informal settlements without relocation is lagging. It is effective for urban expansion because land owner collectively leave their land for development of infrastructures like streets, other public places etc. The general idea of land readjustment is the exchange of land. It does not include land expropriation from municipality or any other investors. Landowners themselves contribute part of their land for public facilities like roads, parks, social buildings. Areas for public services like roads, parking, green spaces, playgrounds are excluded and allocated to the municipality from the whole readjustment area. The remaining area is redistributed to the original landowners. Redistribution to the landowner is based on the relative size or the relative value of their former plots. The new plot area is allocated to the individual land owners with formal decision (Müller-jökel, 2004). It is a method that has been introduced for adjusting irregular land plot boundaries in a regular way with benefits of developed infrastructures and increased land value.

The tool is adopted in many developed as well as developing countries such as Germany, France, Sweden, Indonesia etc (Larsson, 1997). Japan is one of the Asian countries which have a successful implementation of land readjustment, by March 2000 , approximately $30 \%$ of all urban areas had been developed or redeveloped using this method. The tool has also been successfully implemented in Hong kong which have the highest population. The housing demand was very high and availability of land was low. So, to address such issues, vertical application of land readjustment was adopted. The larger buildings with more units which can accommodate many residents was adopted as LR 
(vertical) model and commonly known as flat-forflat model ( $\mathrm{Li}$ and $\mathrm{Li}, 2007)$.

Depending upon the procedures and method, there are various basic conditions for a successful and efficient application of land readjustment (Turk, 2007). The conditions are studied under the social and legal conditions.

\section{Conditions for Application of Land Readjustment}

Social Conditions: Land readjustment can be efficiently implemented only with the public participation. There is intensive participation of all landowners and other parties involved. The process involves landowners consensus at each stage as there is possibility of various hinders in the project application. There are two basic points where landowners can oppose and requires a clear discussion. The first is during land deduction to recover social and technical land development and other is related to distribution.

Legal conditions: Certain condition under the planning is also an important aspect for the application of land readjustment process. Ideal size of land readjustment project areas, connection between the master plan and land readjustment projects are some conditions which arise in regard to the planning(Turk, 2007). Data from the land registration system which are important input for land readjustment should be precise. Various technical difficulties may arise if data is not precise. The cadastral value and the value gained from the measurement of fixed borders on land should be compatible for the efficient application of land readjustment (Turk, 2007) .Cost recovery is one of the important conditions for the efficient application of land readjustment. It is method of self financing and thus is preferred by the public agencies. In order to recover the cost various approaches like selling of reserve land, supply of low interest loan from banks and organizations etc are adopted in different countries (Sorensen, 1999).

\section{Advantages and Disadvantages of Land Readjustment}

Land readjustment has the benefits of win-win strategy as it has the benefits to both parties i.e. communities and local government. Landowners participate in the project by contributing their part of land for the public services. Land owners get benefited from this project as land value is increased despite of the reduction of land size. It helps to convert the irregular plot into the regular and well serviced urban plot. The Government do not get the financial burden of the project as it does not require any expropriation and land purchase. It also includes cost recovery by the sale of some developed plots. (Oli, 2003) Despite of these benefits there are some disadvantages of land readjustment. The distribution of the serviced urban plots is restricted to the original owners only. The plot which is redistributed after the readjustment process may be too small due to the percentage contribution. This may not be suitable in the small scale as in large enough plots and cannot guarantee the decent urban spaces (Supriatna and van der Molen, 2014). It is time consuming procedure as it requires the agreement from each individual land owner (Larsson, 1997)

\subsubsection{Land Readjustment in Nepal}

Land readjustment is commonly known as land pooling. Land pooling is a technique for managing and financing land development with participation of landowners for planning, servicing and subdivision of their land with cost recovery through the sale of reserve plot from the project. Land pooling is found to be effective in Kathmandu to provide infrastructure and services in a planned way. It has not been a long period since it was initiated. This tool was initiated in Kathmandu Valley in 1988 along with the establishment of Ministry of Housing and Physical planning and the enactment of Town Development Act (Karki, 2004). The guidelines to carry out the land pooling projects are stated in the Town Development Act 1988. It acts as a basis to carry out land pooling projects in Nepal which includes procedures and conditions for land owners approval, governmental approval and preparation of replot map i.e. subdivision layout plan and its legalization process to prepare land title certificate. There are various conditions which 
influence the application of land pooling. It needs to deal with large number of landowners and needs consensus at each and every stage. According to Town Development Act, 1998, at least fifty-one percent of land owners should provide the written agreement for implementation of land pooling project. Initial cost of infrastructure development is also an important factor which influences the project. Due to lack of the initial funding some projects like Bagmati corridor, Gopikrishna and Sinamangal Land Pooling Project were delayed. Various strategies were implemented to overcome such issues like mobilizing the fund firstly to the reserved blocks of land such that further funds can be collected by selling them(Karki, 2004). Land records are one of the important factors which have direct influence to the land pooling project. Thus, clear and transparent land records are needed such that the project can be certain about landowner and how much he/she owes. Inaccuracy in cadastre map may create hurdles in implementation of project.

The land is contributed by land owners or tenants for public services and infrastructures. In Nepal, the contribution of land is about $19 \%$ for road, $5 \%$ for open spaces, $8-10 \%$ for infrastructure development and $4 \%$ for administrative cost. Thus in total 35$40 \%$ of land contributed for public services and individual land owner has to contribute $15-55 \%$ of parcel depending upon position of land and infrastructure available. The minimum size for individual parcel should be 80 sq. m. and $6 \mathrm{~m}$ frontage(Oli, 2010).

\subsection{Research Methodology}

Research methodology is the systematic way to solve the research problems. It indicates the different methods and steps used for the conduction of the research. The study is based on the qualitative data collection and analysis. The research was conducted in three different phases i.e. prefieldwork, field work and post field work. Pre-field work included literature review and preparation of interview questionnaire and household survey. Fieldwork included both primary and secondary data collection through interviews with the dwellers of informal settlements and professional from concerned organization. Post fieldwork included data management, data processing and data analysis was carried out for the final conclusion and recommendation.

\section{Case Study Area}

In this research both primary and secondary data was used. The collection of data was carried out in the Kathmandu, Nepal so as to find out the current condition of informal settlement and perspective of various stakeholders for the regularization of informal settlements of Nepal. There are prominent numbers of informal settlements situated along the river banks and also in non-river banks. Most of the informal settlements are along the banks of Bagmati, Bishnumati, Hanumante and Dhobikhola rivers. For this research, one of the informal settlement along the Bagmati river bank i.e. Chadani Tole was selected. Chadani tole was selected for the Fieldwork because of its feasibility for field visit and the settlement is about $12 \mathrm{~m}$ away from Bagmati river such that it is not vulnerable to flood. The settlement is on the western side of Sinamangal chowk along the eastern side of Bagmati river. The settlement has occupied the Guthi Land (Pasupati Trust land) and has been in existence since 2030 B.S. with 56 households.

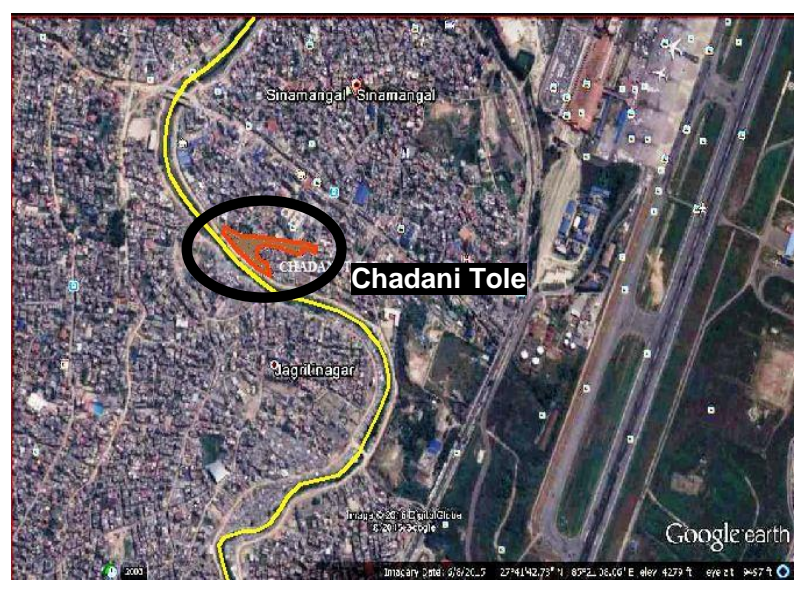

Fig. 1. Case Study Area

\section{Data Collection and Analysis}

Interviews carried out were recorded as these are the important primary data. Snowball sampling was used as a strategy such that network of respondents was formed. Firstly a group of respondent was selected with the help of NBBSS and interviewed. Then with the help of those respondents a network of respondent within the settlement was chosen as 
sample. 30 households among 56 were taken as sample for this research work. This sample is considered adequate in response to the limited timeframe for field study. Survey was based on tenure security and land development in the settlement.

\subsection{Tenure Security}

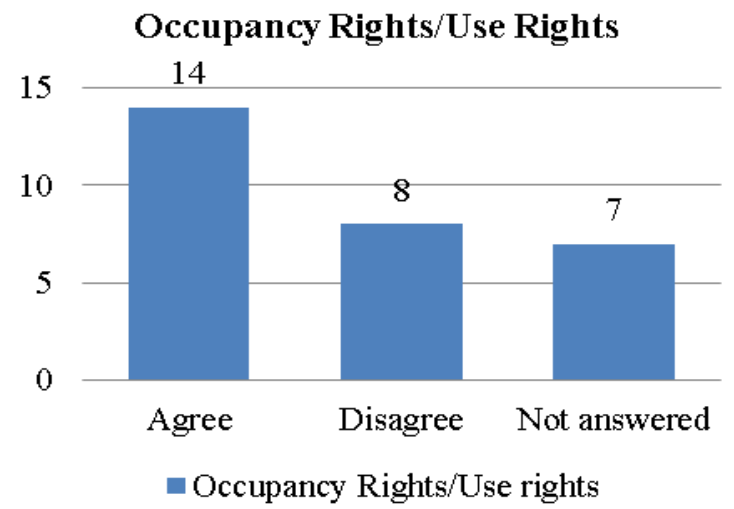

Fig. 2. Bar chart showing Degree of Acceptance on Occupancy Rights/Use Rights

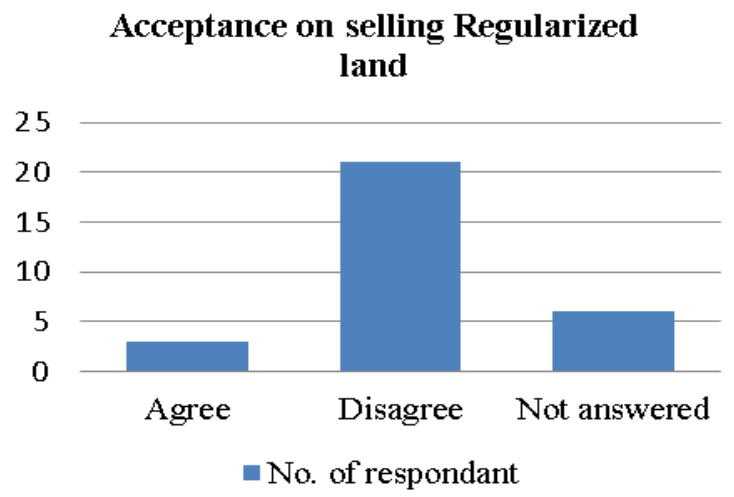

Fig. 3. Bar chart showing Degree of Acceptance on Selling Regularized Land

Since the occupied land is Guthi land (Pashupati Trust), people feel insecure legally. Almost all respondent have legal insecurity regarding their occupancy and all are aware that government might evict them. With the joint effort of local government, municipality and Lumanti (NGO), mapping of informal settlements have been carried out and distributed an identity card with photo. They also have voters card of same area where they are residing. Freehold land titling may not be feasible to the dwellers of informal settlements as there may be possibilities of selling their land and start squatting to other places(Shrestha, 2013). Individual land titling cannot deliver complete tenure security to informal settlements and continuum of rights(occupancy or use rights) is needed (Zevenbergen et al., 2013)

\subsection{Land Development Tool}

Thus a questionnaire relating to the aspects of land readjustment was developed. Regarding land development in Chadani Tole, no any regularization program has been implemented. Most of dwellers among the respondents replied that they want development in same site rather than relocation on other site. In response to the question regarding a good alternative of relocation, some respondent told that they will agree if it covers their socio-economic aspects such as job opportunities for their livelihood and similar social environment as before.Most of the respondent have a positive attitude to compromise on their occupied land and will fully participate on regularization program. Dwellers have shown their positive attitude towards the payment of tax and installment if they gain legal recognition on the occupied land.

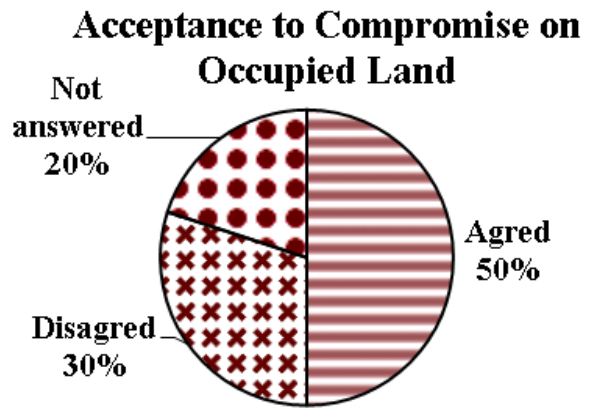

Fig. 4. Bar chart showing Degree of Acceptance to Compromise on Occupied Land

\section{Acceptance on Instalment Payment}

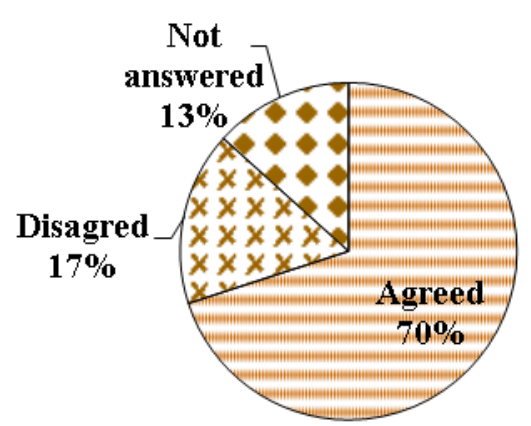

Fig. 5. Bar Chart showing Degree of Acceptance on Installment Payment 
Questionnaire is designed for the interview with the government officials (DUDBC, KVDA), NGOs (LUMANTI, UN-Habitat) and other concerned organization (NBBSS, NMES). Open-ended questionnaire helps to gain in depth information from the interviewee. Thus, open-ended questionnaire has been used for the interviews in the research. The interviews were recorded such that it can be transcribed into written form and qualitative analysis is carried out by coding. Coding helps in labelling certain aspects of data and sorting the information into distinctive categories.Along the Bagmati, Bishnumati, Hanumante and Dhobikhola rivers, there are 24 informal settlements residing. These settlements are highly vulnerable to flood and polluted environment (Lumanti, 2008). Thus, river banks are non habitable land. The settlements along the river are needed to be relocated to a better area. From the interview data coding, a) relocation to better area for river bank settlement, b) land development within the non river bank settlement and c) development of rental housing can be the possible solutions for the regularization to informal settlements. In response to the relocation of informal settlement to better area, Government has initiated apartment for urban poor in Ichhangu Narayan Land Pooling site. DUDBC bought the sales plot for the urban poor in which five apartments has been constructed in a cooperation with KVDA. But due to poor policy of resettlement, it has not been implemented. However, Kirtipur housing project is a successful project to resettle three effected settlements from Vishnumati Link road project (Sengupta and Sharma, 2009).

Informal settlements lack legal rights on their occupied land. Legal recognition encourages the dwellers to mobilize the resources themselves for better and safer housing. So, legal recognition is an important aspect for regularization. The data from interviews reveals that freehold ownership is not feasible to the dwellers and continuum of land rights is needed. Occupancy right certificate can be a possible tenure security. But there are not clear criteria to define informal settlers in land related policy like Land Act 1964 and Land revenue Act, 1978. Current land registration of Nepal does not cater pro-poor and continuum of land rights is not recognized. But however mapping of all informal settlements has been carried out by DUDBC with the effort of supporting organizations. Documentation and recognizing the existence of communities has been carried out along with issue of family identity cards. Land development is another important aspect in regularization of informal settlements. According to the respondent of DUDBC, many land development initiative were taken but informal settlers do not accept those initiatives. As land readjustment, a tool or technique for land development, result shows that it can be implemented only in habitable land. But such initiation may encourage to rebuild new informal settlements. In response to the hurdles of implementation of land readjustment, data coding shows that a) lack of public participation and government b) lack of government policy c) Political influences d) lack of legal documents and e) building Bye-laws are the main hurdles. For implementation of any task, financial support is very important. The land development can be carried out either through government investment or through private investment or through the soft loans to the communities from financial institution.

\section{Result and Discussion}

Different land development techniques like land sharing, upgrading, resettlements or relocation has been carried out for regularization of informal settlement in different countries. LR has been successfully implemented in various places of Nepal. But the application of LR has not been used for regularization of informal settlements. Research focused on the application of land readjustment in the informal settlements (Chadani tole). Thus, social and legal feasibility of LR for the implementation in informal settlements in Chadani tole is carried out.

\subsection{Social Feasibility of $L R$ in Chadani Tole}

Social conditions for the application of LR in Chadani Tole are explained below.

\subsubsection{Community Organization and Public Participation}

LR is initiated by government in Kathmandu valley with fifty one percent of participation of land owners or tenants. In LR there is intensive participation of all parties involved. Clear 
discussion is required for the efficient application of LR. In informal settlements, land occupants need to show their agreement through participation. 76.6 percent of dwellers of Chadani tole showed their interest in participation in LR project which is majority and is a positive aspect for the implementation of LR. Along with public participation, Government participation also plays an important role for the implementation of LR in informal settlements. Government has initiated various land development program in informal settlements but did not succeed due to the problem of acceptance of such initiative by informal settlers and also due to political influences. These circumstances have created ignorance to informal settlers by Government. But views of government and civil society organization show that LR can be implemented in habitable land. From the observation and interview, it shows that the settlement in Chadani Tole is in habitable land. However the settlement is along the Bagmati River but is $12 \mathrm{~m}$ away from the river along with pitched road reducing the risk of flooding. It is also a positive aspect for the implementation of LR in the settlements.

\subsubsection{Well Established Community}

Chadani tole has been in existence since 2030 B.S. Occupancy for substantial period in land has a great influence in the regularization procedure in India and Tanzania. Occupancy period of Chadani tole is more than 40 years which is a long period. Thus regularization of informal settlement in Chadani Tole is to be carried out considering this aspect of regularization. With the passage of time, dwellers share strong social bonding and co-operation. The application of LR faces problems during the land contribution and land distribution. The cooperation and understanding among the occupants helps to reduce such disputes.

\subsubsection{Perception of Tenure Security}

The dwellers of informal settlements lags the legal recognitions but with the passage of time, people gains perceived tenure security within themselves. In case of Chadani tole, people has been residing in the area for more than 40 years and they started investing on their housing which shows that people feel secure of the place where they are residing.
They also have managed to receive public services and infrastructure development like road access, water supply, electricity etc. Thus, perception of tenure security is increased among the occupants. The settlement lacks de jure but feels secure because of de facto.

\subsection{Legal Feasibility of $L R$ in Chadani Tole}

Legal conditions for the application of LR in Chadani Tole are explained below

\subsubsection{Recognitions of Land Rights and Registration}

Recognition of land rights and registration is the main hurdles for the legalization and it is important for the implementation of land readjustment. The implementation of land readjustment is done only after the land registration in countries like Turkey (Magigi and Majani, 2006) and data from land registration are the important input for the implementation of LR(Turk, 2007). The occupied land in Chadani tole is Guthi land and dwellers do not posses legal documents of their occupancy. But they have identity card, electricity bill card and voters card. For the implementation of LR, legal documents and cadastral map is mandatory. This acts as constraints for implementation of LR in Chadani tole. The informal registration through the physical mapping of squatter settlements from NGO has been conducted but is not in national land registration system. The Land registration system of Nepal is based on parcel and it is not flexible enough for identifying different types of land tenure in informal settlements. Pro poor registration can be carried out through STDM as it is developed in fulfilling the gap of land administration system in providing tenure security to informal settlements(Lemmen, 2010). STDM is not only based on the formal land rights registration but also based on the observation of reality that may be informal land rights. Thus land registration of Nepal can be broaden to incorporate STDM and can recognize the legal rights such as occupancy rights or use rights to informal settlers on the occupied land.

\subsubsection{Development Regulations}

LR has been an efficient tool for land development in Nepal. It has been implemented in various places 
of the country. Development regulation is also one of the aspects which play a vital role in implementation of LR in any area. In case of informal settlement in Chadani Tole, the result reveals that there are legal constraints in implementation of LR. According to the Building bye-laws of Kathmandu, 20m setback should be maintained in any construction. But the existing settlement is only $12 \mathrm{~m}$ away from the river such that $8 \mathrm{~m}$ more should be left. This can create difficulty in shifting the dwellers from their occupied land. The occupied land after leaving $8 \mathrm{~m}$ will leave small space that will not be enough for the development of infrastructure, individual plots and service plots for cost recovery. As per the regulation, the minimum parcel size should be 80 sq.meter. The total area occupied by the informal settlers is $5003.50 \mathrm{Sq}$. meter excluding road networks among which 41.07 percent of settlers occupy less than 80sq. meter (Ministry of Physical Planning \& Works, 2010). This is one of the aspects that create hurdles during the contribution of land for service and infrastructure. As shown in Fig 6, 35\% of land is to be contributed for the public services and infrastructure which leaves 1751.25 sq. $\mathrm{m}$ land. It is insufficient for 56 families to provide minimum plot. Insufficient land area is one of the hurdles for implementation of land readjustment in Chadani Tole.

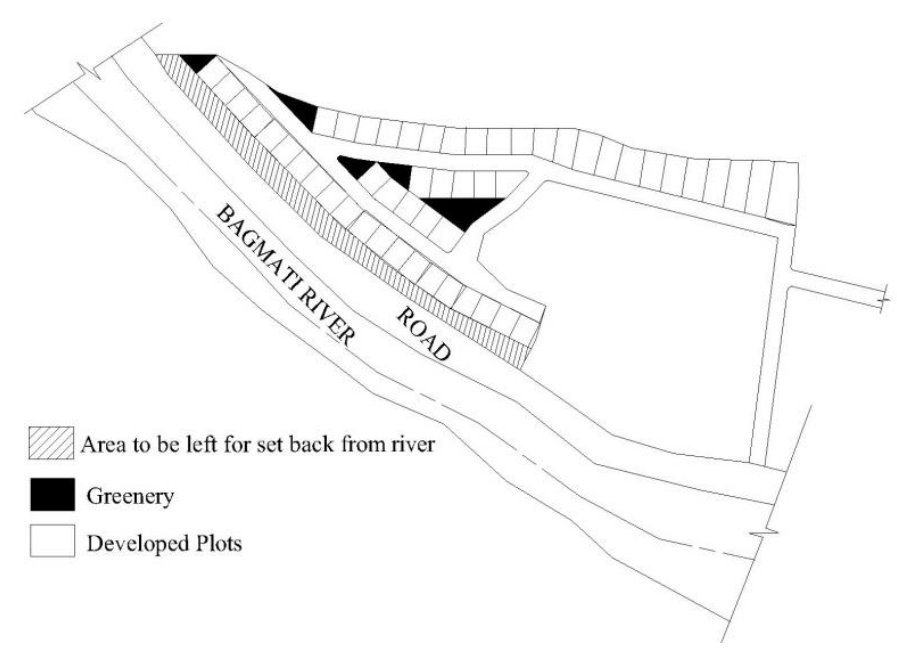

Fig. 6. Land Readjustment in Chadani tole

Multi-storey building within the area can be a suitable approach such that it will be sufficient to locate all the dwellers and enough for public services and basic infrastructures. Vertical application of land readjustment as applied in Hong Kong can be used in the settlement. Larger buildings with more units which can accommodate many residents was adopted in Hongkong as LR (vertical) model commonly known as flat-for-flat model(Li and $\mathrm{Li}, 2007)$. Nepal also has the legal provision for the construction of multi-storey apartment which has been mentioned in Joint Apartment Resident Act 1997. Thus, multi-storey buildings within the area will help all the dwellers to access the units with secure tenure and can also provide units to poor and needy people in other parts of the cities.

\subsubsection{Financial Arrangements}

Financial arrangement is one of the important aspects for the regularization of informal settlements. Soft loans can be provided to the dwellers with the payment in installment basis as in case of Turkey. In case of Chadani Tole, the initial cost of administrative cost can be made available through the government or donor agency and 70 percent of the respondents of chadani tole agreed for the installment payment. In case of LR, the service plots are sold for the cost recovery. While in case of Chadani Tole, the considerable numbers of service plots cannot be developed due to small site area which is the constraints. As described in previous aspects, vertical application of land readjustment will help to develop the service plots for cost recovery.

\section{Conclusion}

LR tool aims to provide the basic infrastructure in poorly planned urban areas with landowners' contribution and is cost recovery through the sale of reserve plot. LR is a tool which has been effectively implemented in Kathmandu to provide infrastructure and services in a planned way. There are many land readjustment project which has been successfully implemented in Nepal but its implementation in informal settlement is very rare. LR is initiated by the government and KVDA is only organization which is responsible for the implementation of LR. LR need to deal with large number of landowners and requires intensive participation of all parties involved. Public participation is one of the important aspects which influence the application of 
LR. The case of Chadani Tole reveals that 76.6 percent of dwellers have shown their interest in participation in LR project which is a positive aspect for the implementation of LR. However, Government seems to have least interest in application of LR but views of government and civil society organization show that LR can be implemented in habitable land. Public participation showed the positive feasibility for the LR implementation.

According to Sukumbasi Samashya samadhan aayog, 2071, dwellers living in the habitable land are preferred to provide land on the same site and those who living in non habitable land are preferred to provide land in nearby area. The informal settlement in Chadani Tole is located along the Bagmati river and is $12 \mathrm{~m}$ away from the river bank. It is not vulnerable to the flooding. Considering it, LR can be implemented in the settlement. There are some legal constraints like land registration, development regulations in implementation of LR in Chadani Tole. Due to low availability of land, it is difficult to develop infrastructures, individual developed plots and service plots for cost recovery. So, applicability of LR becomes quite difficult in the area. Thus to address the issue and ascertain the rights of dwellers to live in the same land, high rise building within the area can be adopted such that it will be sufficient to locate all the dwellers and can provide enough area for public services and basic infrastructure. Hence applicability of LR in informal settlements can be possible overcoming the social and legal hurdles.

\section{References}

[1] Berrisford, S., Base, B. A., Ulk, F. O. R., In, D., \& Habitat, U. N.. (2012) 'UN - Habitat Strategy Report on Urban Legal Knowledge’.

[2] Fernandes, E. (2011). Regularization of Informal Settlements in Latin America.

[3] Karki, T. K. (2004) 'Implementation experiences of land pooling projects in Kathmandu Valley', Habitat International, 28(1), pp. 67-88.

[4] Larsson, G. (1997) 'Land readjustment: A tool for urban development', Habitat International, 21(2), pp. 141152.
[5] Lemmen, C. (2010) 'A Pro-Poor Land Tool', (52).

[6] Li, L. and Li, X. (2007) 'Land Readjustment: An Innovative Urban Experiment in China’, 44(1), pp. 8198.

[7] Lumanti (2008) 'Status of squatter communities along bagmati river and its tributaries in kathmandu valley, Lumanti Support Group for Shelter February 2008'.

[8] Magigi, W. and Majani, B. B. K. (2006) 'Community involvement in land regularization for informal settlements in Tanzania: A strategy for enhancing security of tenure in residential neighborhoods', Habitat International, 30(4), pp. 1066-1081.

[9] Ministry of Physical Planning \& Works, D. (2010) Physical Mapping of the Squatter Settlements situated along the Bagmati River Corridor (North-South) in the Kathmandu Valley.

[10] Müller-jökel, R. (2004) 'Land Readjustment - A WinWin-Strategy for Sustainable Urban Development', pp. $1-7$.

[11] Oli, P. P. (2003) 'Land Pooling: The Public Private Participatory Urban Development in Nepal', pp. 1-13.

[12] Oli, P. P. (2010) 'Land Pooling / Readjustment Programmes in Nepal Land Pooling / Readjustment Programmes in Nepal', pp. 11-16.

[13] Özdemirli, Y. K. (2014) 'Alternative strategies for urban redevelopment: A case study in a squatter housing neighborhood of Ankara', Cities, 38, pp. 3746.

[14] Potsiou, C. (2014) 'Policies for formalization of informal development: Recent experience from southeastern Europe', Land Use Policy, 36, pp. 33-46.

[15] Ramadhani, S. H. (2007) 'Effect of Tenure Regularization Programme on Building Investment in Manzese Ward in Dar es Salaam, Tanzania'.

[16] Sengupta, U. and Sharma, S. (2009) 'No longer Sukumbasis: Challenges in grassroots-led squatter resettlement program in Kathmandu with special reference to Kirtipur Housing Project', Habitat International, 33(1), pp. 34-44.

[17] Shrestha, B. K. (2013) 'Squatter Settlements in the Kathmandu Valley: Looking Through the Prism of Land Rights and Tenure Security', Urban Forum, 24(1), pp. 119-135. 
[18] Shrestha, P. (2001) 'Urban governance, planning and housing policy'.

[19] Shrestha, R., Tuladhar, A. and Zevenbergen, J. (2014) “" Decades of Struggle for Space ": About the Legitimacy of Informal Settlements in Urban Areas'.

[20] Sorensen, A. (1999) 'Land Readjustment, Urban Planning and Urban Sprawl in the Tokyo Metropolitan Area', Urban Studies, 36(13), pp. 2333-2360..

[21] Supriatna, A. and van der Molen, P. (2014) 'Land readjustment for upgrading Indonesian kampung: a proposal', South East Asia Research, 22(3), pp. 379397.

[22] Turk, S. S. (2007) 'An analysis on the efficient applicability of the land readjustment ( LR ) method in Turkey', 31, pp. 53-64.

[23] UN-HABITAT (n.d.) 'Operational policy framework to address the shelter needs of urban poor particularly those living in informal settlements volume I of III'.

[24] Zevenbergen,J., Augustinus, C., Antonio, D., \& Bennett, R. (2013) 'Pro-poor land administration: Principles for recording the land rights of the underrepresented', Land Use Policy, 31, pp. 595-604. 